\title{
Does Core Competence Affect Corporate Social Responsibility?
}

- Changling Sun, Stanislav Skapa, Jinzhao Liu, Jakub Horak, Yaning Yang

\begin{abstract}
Core competence is the key factor in the competitiveness of enterprises. This study examines whether enterprises with stronger core competence have the ability and motivation to fulfill more corporate social responsibilities. Taking the non-financial companies listed in the A-share market in China from 2010 to 2019 as the research samples, this paper constructs the measurement index of core competence by text analysis method and empirically tests the impact of core competence on corporate social responsibility. We find that the stronger the core competence is, the higher the corporate social responsibility will be, which means core competence can significantly improve corporate social responsibility. This conclusion remains significant after a series of robustness tests. The mechanism test shows that the impact of core competence on corporate social responsibility is realized by enhancing financial strength and increasing external attention. Further research shows that the relationship between core competence and corporate social responsibility are affected by the nature of the enterprise and the degree of market competition. When the enterprise is a non-state-owned enterprise or the industry competition is more intense, the influence of core competence on corporate social responsibility is stronger. This paper reveals the important impact of core competence on corporate social responsibility, which not only enriches the literature on the economic consequences of core competence and the influencing factors of corporate social responsibility but also has a certain practical significance for how to improve corporate social responsibility.
\end{abstract}

Keywords: core competence, corporate social responsibility, financial strength, external attention JEL Classification: G30, M00, M14

Received: July, 2021

1st Revision: October, 2021

Accepted: October, 2021

\section{INTRODUCTION}

With the proposal of Stakeholder Theory, Corporate Citizenship Theory, and the vigorous development of the global social responsibility movement, the investment and performance in social responsibility have become an important criterion to judge the quality of a company (Lins et al., 2017; Flammer, 2015; Kitzmueller \& Shimshack, 2012; Porter \& Kramer, 2011). China's regulatory authorities have successively issued a number of policies to encourage and guide 
companies to fulfill their social responsibilities. Besides, the public's requirements for corporate social responsibility are constantly increasing. In this context, it is of great theoretical value and practical significance to explore the influencing factors of social responsibility.

Previous scholars have studied many influencing factors of corporate social responsibility, but less discussion has taken place on whether core competence can affect corporate social responsibility. Nowadays, human society has stepped into the era of the digital economy. The ever-blurring industry boundaries, ever-shortening product cycles and ever-expanding scope of competition lead to the greatly increased competitive pressure and operational risks of enterprises. Cultivating and consolidating core competence is not only the key factor in improving the competitiveness of enterprises (Sun et al., 2021a; Zhang \& Gao, 2013; Wang et al., 2021a; Sabah et al., 2012) but also an important factor affecting the degree of corporate social responsibility fulfillment. Theoretically, adequate funding is a basic prerequisite for enterprises to fulfill their social responsibilities (Elliott et al., 2014; Yin et al., 2014; Lys et al., 2015; Wang et al., 2018). As the source of sustainable competitive advantage, core competence can not only provide adequate financial support when enterprises fulfill their social responsibilities (Sun et al., 2021a; Wang et al., 2021a; Sabah et al., 2012) but also can enable enterprises to maintain normal operation and development during the lag period of social responsibility activity transforming into financial performance (Li et al., 2018; Li et al., 2020; Servaes \& Tamayo, 2013). Therefore, enterprises with strong core competence have a stronger ability to fulfill social responsibilities. On the other hand, enterprises with strong core competence will attract more attention from the outside world. Their information communication channels are better, which can not only guarantee the wide dissemination of corporate information to realize the value creation of social responsibility activities but also supervise enterprises to be punished more severely when they evade social responsibility or fail to meet public expectations (Zyglidopoulos et al., 2012; Zhang et al., 2013; Wang et al., 2015). Therefore, enterprises with a strong core competence also have stronger motivation to fulfill their social responsibilities and eventually, establish a dual image of "strong core competence" and "good sense of responsibility".

Based on the above, this paper aims to empirically test the impact of core competence on corporate social responsibility. Taking the non-financial companies listed in the A-share market in China from 2010 to 2019 as the research samples, this paper constructs the measurement index of corporate core competence through text analysis and finds a positive effect of core competence on fulfilling corporate social responsibility. The mechanism test shows that the impact of core competence on corporate social responsibility is realized by enhancing financial strength and increasing external attention. Further research shows that the relationship between core competence and corporate social responsibility is affected by the nature of the enterprise and the degree of market competition. When the enterprise is a non-state-owned enterprise or the industry competition is more intense, the influence of core competence on corporate social responsibility is stronger.

The research contributions of this paper are mainly reflected in the following three aspects. Firstly, this paper enriches the relevant literature on the economic consequences of core competence. Existing studies basically reached a consensus that core competence can help enterprises obtain long-term excess returns and reduce the level of the leverage ratio, etc. (Sabah et al., 2012; 
Sun et al., 2021a). This study finds that core competence can significantly improve corporate social responsibility, enriching the relevant literature on the economic consequences of core competence. Secondly, this paper supplements the relevant literature on the influencing factors of corporate social responsibility. Scholars have studied the effect of enterprise size (Ting, 2021), corporate governance (Arora \& Dharwadkar, 2011), financial performance (Zhang et al., 2013; Yin et al., 2014), corporate culture (Jin, 2017), external attention (Zyglidopoulos et al., 2012; Jia et al., 2016) and the degree of market competition (Flammer, 2015; Zhou \& Tang, 2015) on corporate social responsibility, this paper finds that core competence is also an important factor affecting the implementation of social responsibility. Thirdly, this paper clarifies the influencing mechanism of core competence on corporate social responsibility. This study shows that the impact of core competence on corporate social responsibility is realized through two ways, namely, enhancing financial strength and increasing external attention, clarifying the affecting mechanism of core competence on corporate social responsibility.

The remainder of the paper is organized as follows: the second section describes a theoretical background; the third reports the research objective, methodology and data; the fourth part communicates results and a discussion, and the fifth reports the conclusion.

\section{THEORETICAL BACKGROUND}

\subsection{The Economic Consequences of Core Competence}

Because of the difficulty in measuring core competence, the research on the economic consequences of core competence is mainly based on theoretical analysis (Ljungquist, 2013; Chen \& Chang, 2011). The empirical research, especially large sample empirical research, is relatively few.

Theoretically, core competence has the characteristics of value, scarcity, irreplaceable and imitative, which is the source of a company's sustainable competitive advantage (Sun et al., 2021a; Sun et al., 2021b; Wang et al., 2021a; Lu \& Sun, 2013; Sabah et al., 2012). Competitive advantage is a sustainable advantage over competitors, which refers to a firm's ability to create more economic value in the product market than its competitors (Madsen \& Leiblein, 2015; Wang et al., 2021b) and the extent to which an enterprise can grasp opportunities, eliminate threats and reduce costs compared with its competitors. Competitive advantage can create value for customers, which in turn can bring good performance and excess returns to enterprises (Wang et al., 2021a; Sun et al., 2021; Lazzarini, 2015). Therefore, core competence can help enterprises achieve excellent performance in the fierce market competition and have strong profitability and capital strength.

Empirically, some scholars measure the level of core competence of enterprises using questionnaire survey (Sabah et al., 2012) or case study (Sun, 2014), and others have selected specific metrics to measure some particular kind of core competence of enterprises within a single industry (Liang et al., 2013; Denicolai et al., 2010). They all confirmed that core competence helps to improve the enterprises' financial performance. Sun et al. (2021a) constructed the measurement index of enterprise core competence with the method of text analysis and confirmed that enterprise core competence could help enterprises to deleverage, which provided a reference for large sample empirical research on the topic of core competence. 


\subsection{The Influential Factors of Corporate Social Responsibility}

At present, most academic circles focus on discussing the economic consequences of corporate social responsibility and the path of value creation. The works of literature on the influencing factors of social responsibility are relatively few. Among them, financial strength and external attention are two factors that scholars have studied more. The former corresponds to the ability level of enterprises to fulfill social responsibility, while the latter corresponds to the motivation intensity of enterprises to fulfill social responsibility.

From the perspective of ability, adequate funding is a basic prerequisite for a company to fulfill its social responsibility (Elliott et al., 2014; Yin et al., 2014; Lys et al., 2015; Wang et al., 2018). Inevitably, enterprises need to pay some costs to fulfill their social responsibilities, including the direct economic cost in need of financial support and the opportunity cost caused by fulfilling social responsibilities (Sprinkle \& Maines, 2010; Zhu, 2011). However, its earnings are often reflected in non-monetized forms such as reputation and market recognition. There is a certain lag when non-monetized earnings are converted into monetary earnings (Li et al., 2018; Li et al., 2020; Servaes \& Tamayo, 2013). At the same time, the information of enterprises' social responsibility activities is likely to be interfered with by other irrational factors in the process of transmission, leading to stakeholders' failure to timely and comprehensively understand the enterprises' behaviors, and thus unable to generate positive cognitive feedback (Zhang et al., 2013). Therefore, there is a lag in transforming social responsibility activities into financial performance (Li et al., 2018; Li et al., 2020). During the lag period, the enterprise needs sufficient funds to guarantee its normal development and operation.

From the perspective of motivation, external attention is an important driving factor for enterprises to fulfill their social responsibilities (Ghoul et al., 2019; Zyglidopoulos et al., 2012; Tao \& Jin, 2012; Jia et al., 2016; Kong et al., 2013). External attention measures the degree to which an enterprise is concerned by the market and public opinion (Kong et al., 2013; Jia et al., 2016) and represents the possibility that corporate social responsibility information can survive and finally be perceived by stakeholders (Ghoul et al., 2019; Zhang et al., 2013). Therefore, on the one hand, a higher degree of external attention can accelerate the transformation process of corporate social responsibility to financial performance and then encourage enterprises to fulfill more social responsibilities. On the other hand, it can also enhance the supervision effect of the external market, so that enterprises will be severely punished when they evade their social responsibilities or fail to meet public expectations (Tao \& Jin, 2012; Wang et al., 2015). Therefore, greater external attention can promote enterprises to fulfill more social responsibilities.

In addition, some scholars have also explored the influencing factors of social responsibility from the perspective of the scale of enterprises (Ting, 2021), corporate governance (Arora \& Dharwadkar, 2011), the feature of the CEO (Wu et al., 2015), financial performance (Elliott et al., 2014; Zhang et al., 2013; Yin et al., 2014), corporate culture (Jin, 2017), degree of industry competition (Flammer, 2015; Zhou \& Tang, 2015) and others. 


\subsection{Core Competence and Corporate Social Responsibility}

When the core competence is stronger, the enterprise can not only improve the ability to fulfill corporate social responsibility but also increase its motivation and promote the enterprise to fulfill corporate more social responsibility finally.

From the perspective of ability, core competence is valuable, scarce, irreplaceable and difficult to imitate, which is the source of sustainable competitive advantage of enterprises (Sun et al., 2021a; Sun et al., 2021b; Wang et al., 2021a; Lu \& Sun, 2013), can help enterprises to achieve outstanding performance in the fierce market competition (Wang et al., 2021a; Sun et al., 2021; Lazzarini, 2015). Therefore, enterprises with strong core competence have stronger profitability and financial strength (Chen \& Chang, 2011). This can not only provide financial support when enterprises fulfill social responsibilities but also make up for the short-term operating costs brought by social responsibility activities through their cash during the lag period when social responsibility activities are translated into economic performance to maintain their normal operation and development. Therefore, enterprises with stronger core competence can fulfill more social responsibilities.

From the perspective of motivation, as the leaders of various industries, enterprises with stronger core competence will be given higher expectations by the public, thus attracting more attention from the market (Tao \& Jin, 2012). The higher the external attention, the closer the information dissemination. Therefore, the interference of other factors in the process of information transmission will be alleviated so that stakeholders can know the social responsibility behavior of enterprises more quickly and completely (Zhang et al., 2013). On the one hand, this can shorten the lag period of value creation and improve the enthusiasm of enterprises to fulfill their social responsibilities (Zyglidopoulos et al., 2012; Kong et al., 2013). On the other hand, an external supervision mechanism can be formed so that enterprises will be punished more severely when they evade their social responsibilities or fail to meet public expectations (Tao \& Jin, 2012; Wang et al., 2015). Therefore, enterprises with stronger core competence can attract more external attention, which can enhance the motivation to fulfill their social responsibility from both the incentive and supervision aspects.

\section{RESEARCH OBJECTIVE, METHODOLOGY AND DATA}

\subsection{Research Objective}

The research objective of this paper is to explore the impact of core competence on corporate social responsibility. According to the description in the second section, enterprises with stronger core competence have the ability and motivation to fulfill more social responsibilities. Therefore, hypotheses $\mathrm{H} 1-\mathrm{H} 3$ are proposed in this paper.

H1: Enterprises with stronger core competence will fulfill more social responsibilities.

H2: Core competence can enhance the financial strength of enterprises and thus increase their ability to fulfill more social responsibilities.

H3: Core competence can bring greater external attention to enterprises and thus motivate enterprises to fulfill more social responsibilities. 


\subsection{Methodology}

To test the hypothesis of this study, this paper constructs the following multiple linear regression model:

$$
\operatorname{CSR}_{i, t}=\beta_{0}+\beta_{1} \operatorname{CORE}_{i, t}+\operatorname{ECONTROLS} S_{i, t}+\text { Industry }+ \text { Year }+\varepsilon
$$

CSR represents corporate social responsibility. CORE represents the level of enterprise's core competence; $\Sigma$ CONTROLS represent related control variables; Industry and Year represent industry and year dummy variables, respectively. In this paper, we mainly focus on the regression results of $\beta_{1}$ : if the regression results of $\beta_{1}$ are significantly positive, then hypothesis $\mathrm{H} 1 \mathrm{can}$ be proved. That is, enterprises with stronger core competence have a higher degree of social responsibility fulfillment.

Referring to Wang \& Xu (2016) and Wang et al. (2018), this paper uses the third-party rating agency "Hexun" scoring results to measure the degree of corporate social responsibility fulfillment. This index system is based on corporate social responsibility reports and annual reports. It examines the degree of corporate social responsibility fulfillment from five aspects: Shareholders, Employees, Suppliers, Customers and Consumers, Environment, and Government and the Public (According to the evaluation index system of "Hexun", this project is about the tax payment and donation of enterprises, which is named "social responsibility". In order to avoid confusion for readers, this paper refers to the naming method of Wang \& Xu (2016) and names it "responsibility to the government and the public"), which are finally totaled up to get the result of corporate social responsibility (CSR). The higher the value, the higher the degree of social responsibility fulfillment of listed companies. In the Hexun evaluation index system, "Shareholder Responsibility" accounts for the highest proportion, which is up to $30 \%$, and the result depends on the level of financial performance to a great extent. To distinguish it from the principle of "Shareholder Primacy Theory" in the traditional corporate theory and improve the universality of the empirical results, this paper excluded the result of "Shareholder Responsibility" from the total CSR score and constructed CSR_EXP to perform synchronous regression.

Referring to Sun et al. (2021), the data of core competence is collected from the annual reports of Chinese listed companies through text analysis and manual collection. Precisely, this paper measures the strength of corporate core competences with their kind and intensity calculated by Python according to the dictionaries of each kind of core competence. For example, if the text analysis result of Python shows that the corporate $i$ has two types of core competence: brand and technology. In the paragraphs of core competence, there are 3 dictionaries reflecting the core competence of the brand and 2 dictionaries reflecting the core competence of technology; then, the corporate i's core competence kind is 2 , and the corporate i's core competence intensity is 5 . To make results easier to analyze, for each corporate, we use ln (core competence intensity +1 ) to measure its strength of core competence. To ensure the effectiveness of the measurement, we also use $\ln$ (core competence kind +1 ), core competence intensity, and core competence kind as alternative measurement indexes in the robustness tests and the empirical results are consistent.

Referring to Zhang et al. (2013), factors such as enterprise characteristics, profitability, ownership structure, corporate governance and business environment have also been controlled. The definitions of variables in detail are shown in Table 1. 
Tab. 1 - Variable definition. Source: own research

\begin{tabular}{|c|c|c|}
\hline & Variable & Explanation \\
\hline \multirow{2}{*}{$\begin{array}{l}\text { Dependent } \\
\text { Variable }\end{array}$} & CSR & $\begin{array}{l}\text { Corporate social responsibility total score from "Hexun" (the } \\
\text { sum of the scores of shareholders, employees, suppliers, cus- } \\
\text { tomers and consumers, environment and government and the } \\
\text { public) }\end{array}$ \\
\hline & CSR_EXP & $\begin{array}{l}\text { Remaining scores excluding the shareholder scores from CSR } \\
\text { (the sum of the score results of employees, suppliers, customers } \\
\text { and consumers, environment, government and public) }\end{array}$ \\
\hline $\begin{array}{l}\text { Indepen- } \\
\text { dent Vari- } \\
\text { able }\end{array}$ & CORE & $\ln ($ core competence intensity +1$)$ \\
\hline \multirow{11}{*}{$\begin{array}{l}\text { Controlled } \\
\text { variables } \\
(\mathrm{CV})\end{array}$} & SIZE & Natural logarithm of total assets \\
\hline & AGE & Natural logarithm of the company's establishment years \\
\hline & LEV & Rate of total liabilities to total assets \\
\hline & $\mathrm{ROA}$ & Rate of net profit to total assets \\
\hline & GROWTH & $\begin{array}{l}\text { The difference in sales income between beginning and closing } \\
\text { divided by the beginning sales income }\end{array}$ \\
\hline & $\mathrm{RD}$ & Rate of R\&D investment to revenue \\
\hline & SOE & $\begin{array}{l}\text { If the company is state-owned, the SOE equals } 1 \text {; If not, the } \\
\text { SOE equals to } 0\end{array}$ \\
\hline & INDEXZ & $\begin{array}{l}\text { Rate of the shareholding ratio between the largest shareholder } \\
\text { and the second-largest shareholder }\end{array}$ \\
\hline & INDEPEN & $\begin{array}{l}\text { Rate of the number of independent directors to the total num- } \\
\text { ber of directors }\end{array}$ \\
\hline & LIST & $\begin{array}{l}\text { If the company is listed on the Shanghai Stock Exchange, the } \\
\text { LIST equals } 1 \text {; If not, the LIST equals } 0\end{array}$ \\
\hline & $\mathrm{MKT}$ & $\begin{array}{l}\text { The Fangang Marketization Index score result of the province } \\
\text { where the enterprise is registered }\end{array}$ \\
\hline
\end{tabular}

\subsection{Data}

Since Hexun began to score the performance of social responsibility of listed companies in 2010, this paper takes taking the companies listed in the A-share market in China from 2010 to 2019 as the research samples. The CSR scoring data comes from the third-party rating agency Hexun. The core competence data is the result of manual sorting and text analysis on the annual report of listed companies. Other data are from the CSMAR Database. According to the previous research methods, the sample data are processed as follows: (1) Due to the particularity of financial industry business and accounting treatment, companies in the financial industry are excluded; (2) Since most ST companies cannot meet the basic accounting assumptions of going concerned, ST companies are excluded; (3) Delete data missing samples; (4) We winsorize all continuous variables at both the 1st and 99th percentiles to mitigate the effect of outliers. After the screening, we come up with a sample of 15,585 firm-year observations. 


\section{RESULTS AND DISCUSSION}

Table 2 shows the descriptive statistical results of the main variables in this paper. The average value of CSR of Chinese listed companies is 23.794. After eliminating the responsibility subject of "shareholders", the average value of CSR_EXP is 9.525, which indicates to a certain extent that the degree of social responsibility performance of Listed Companies in China needs to be further improved (The total score of Hexun is 100 points, and 70 points after excluding "shareholders"). Other variables are not detailed. By comparison, the descriptive statistical results of this paper are consistent with the relevant studies.

Tab. 2 - Descriptive statistics of the main variables. Source: own research

\begin{tabular}{|l|l|l|l|l|l|l|}
\hline Variables & $\mathrm{N}$ & Mean & Median & St. Dev. & Min. & Max. \\
\hline CSR & 15585 & 23.794 & 21.680 & 15.057 & -3.000 & 74.420 \\
\hline CSR_EXP & 15585 & 9.525 & 5.860 & 12.393 & -5.040 & 54.000 \\
\hline CORE & 15585 & 2.631 & 2.773 & 0.675 & 0.693 & 3.829 \\
\hline SIZE & 15585 & 22.143 & 21.952 & 1.257 & 20.000 & 26.135 \\
\hline AGE & 15585 & 2.827 & 2.890 & 0.333 & 1.792 & 3.466 \\
\hline LEV & 15585 & 0.403 & 0.391 & 0.198 & 0.052 & 0.867 \\
\hline ROA & 15585 & 0.041 & 0.038 & 0.055 & -0.208 & 0.193 \\
\hline GROWTH & 15585 & 0.181 & 0.118 & 0.380 & -0.461 & 2.376 \\
\hline RD & 15585 & 0.044 & 0.035 & 0.044 & 0.000 & 0.255 \\
\hline SOE & 15585 & 0.317 & 0.000 & 0.465 & 0.000 & 1.000 \\
\hline INDEXZ & 15585 & 8.388 & 3.449 & 13.601 & 1.002 & 88.074 \\
\hline INDEPEN & 15585 & 0.376 & 0.353 & 0.054 & 0.333 & 0.571 \\
\hline LIST & 15585 & 0.340 & 0.000 & 0.474 & 0.000 & 1.000 \\
\hline MKT & 15585 & 8.254 & 9.054 & 1.649 & 3.450 & 10.000 \\
\hline
\end{tabular}

Note: $\mathrm{N}$ - Number of Samples

\subsection{Main Regression Results}

Table 3 reports the regression results of the model (1). The regression results show that among the four results, the regression coefficients of core competence are significantly positive at the level of $1 \%$. After adding the control variables, the regression coefficients of core competence are $0.880(t=5.68)$ and $0.581(t=4.18)$, which show that the stronger the core competence of enterprises, the higher the degree of social responsibility. Therefore, hypothesis H1 is proved.

Tab. 3 - Core competence and corporate social responsibility. Source: own research

\begin{tabular}{|l|l|l|l|l|}
\hline & CSR & CSR & CSR_EXP & CSR_EXP \\
\hline CORE & $1.543 * * *$ & $0.880^{* * *}$ & $0.439 * * *$ & $0.581^{* * *}$ \\
\hline & $(8.64)$ & $(5.68)$ & $(3.11)$ & $(4.18)$ \\
\hline CV & NO & YES & NO & YES \\
\hline
\end{tabular}




\begin{tabular}{|l|l|l|l|l|}
\hline INDUSTRY & YES & YES & YES & YES \\
\hline YEAR & YES & YES & YES & YES \\
\hline $\mathrm{N}$ & 15585 & 15585 & 15585 & 15585 \\
\hline Adj-R ${ }^{2}$ & 0.11 & 0.35 & 0.13 & 0.20 \\
\hline
\end{tabular}

Note: $T$ values in brackets are obtained after heteroscedasticity (robust) correction; *** indicates significance at $1 \%$ levels. "YES" or "NO" means if the result controls controlled variables (CV), industry effect (INDUSTRY), year effect (YEAR) or not.

To verify the robustness of the main regression results, this article has done the following robustness tests and endogenous tests. (1) Referring to Zhou et al. (2012), this paper takes the total score result of Runling Global's listed corporate social responsibility score data as a substitute variable of corporate social responsibility. (2) Referring to Sun et al. (2021), this paper takes CORE1 $=\ln ($ core competence kind +1$)$, CORE2 $=$ core competence intensity, CORE3= core competence kind, CORE4= core competence index constructed by the expert scoring method as the substitute variables of core competence. (3) In order to alleviate the endogenous problem, this paper takes "year-industry" median core competence (CORE_MED) as the instrumental variable and re-performs two-stage least square regression (2SLS). (4) In order to further alleviate the endogenous problem, this paper controls the firm fixed effect in model (1) and carries out the regression again. (5) In order to further alleviate the endogenous problem, the explanatory variables and the control variables were put into the model (1) with a lag period for regression. All above results further support the conclusion of this paper.

\subsection{Mechanism Test}

\subsubsection{Mechanism Test: Financial Strength}

As H2 mentioned above, core competence can enhance the financial strength of enterprises and thus be able to make corporates fulfill more social responsibilities. Based on this, this paper uses the mediating effect model to test whether the core competence can improve corporate social responsibility through enhancing financial strength. Referring to Wu (2013), we adopt "networking capital/total assets" to measure the financial strength (FS) of enterprises (In order to ensure the robustness of the results, this paper also uses ROA and ROE as the measurement of financial strength to test the mediating effect, and the regression results are still robust.). Table 4 lists the test results. The first three columns list the mediating effect test results when CSR is taken to measure corporate social responsibility. The last three columns list the mediating effect test results when CSR_EXP is taken to measure corporate social responsibility. For the sake of concise, the empirical results of CSR measurement of corporate social responsibility are taken as an example for analysis (the mediating effect test results of CSR_EXP measurement of corporate social responsibility also support the conclusion). Firstly, Column 1 lists the regression result of the first step of the mediation effect test. The regression result shows that the coefficient of CORE competence is $0.880, t=5.68$, which is significantly positive at the level of $1 \%$. Secondly, Column 2 lists the regression results of the second step of the mediation effect test. The regression result shows that the coefficient of core competence is $0.007, \mathrm{t}=3.42$, which indicates that core competence can significantly enhance the capital strength of enterprises. Finally, Column 3 lists the regression results of the third step of the mediation effect test. The regression 
result shows that after adding financial strength (FS) into the model, the coefficient of financial strength (FS) is $4.977, \mathrm{t}=7.48$, which is significantly positive at the $1 \%$ level. The coefficient of core competence is $0.848, \mathrm{t}=5.48$, which is significantly positive at the level of $1 \%$, and the coefficient of core competence (CORE) in Column 3 decreases compared with that in Column 1. Besides, the regression results pass the Sobel Test of intermediary effect $(Z=3.11, P=0.00)$, which indicates that financial strength (FS) plays a partial intermediary role between core competence (CORE) and corporate social responsibility (CSR). In other words, enterprises with stronger core competence have stronger capital strength and can fulfill more social responsibilities, so the degree of social responsibility fulfillment is higher.

Tab. 4 - Mechanism Test: Financial Strength. Source: own research

\begin{tabular}{|l|l|l|l|l|l|l|}
\hline & CSR & FS & CSR & CSR_EXP & FS & CSR_EXP \\
\cline { 2 - 7 } & $(1)$ & $(2)$ & $(3)$ & $(4)$ & $(5)$ & $(6)$ \\
\hline CORE & $0.880^{* * *}$ & $0.007 * * *$ & $0.848^{* * *}$ & $0.581^{* * *}$ & $0.007 * * *$ & $0.565^{* * *}$ \\
\hline FS & $(5.68)$ & $(3.42)$ & $(5.48)$ & $(4.18)$ & $(3.42)$ & $(4.07)$ \\
\hline & & & $4.977 * * *$ & & & $2.425^{* * *}$ \\
\hline CV & & & $(7.48)$ & & & $(4.03)$ \\
\hline INDUSTRY & YES & YES & YES & YES & YES & YES \\
\hline YEAR & YES & YES & YES & YES & YES & YES \\
\hline N & 15585 & 15585 & 15585 & 15585 & 15585 & 15585 \\
\hline Adj-R ${ }^{2}$ & 0.35 & 0.64 & 0.35 & 0.20 & 0.64 & 0.20 \\
\hline
\end{tabular}

Note: $\mathrm{T}$ values in brackets are obtained after heteroscedasticity (robust) correction; $* * *$ indicates significance at $1 \%$ levels. "YES" or "NO" means if the result controls controlled variables (CV), industry effect (INDUSTRY), year effect (YEAR) or not.

\subsubsection{Mechanism Test: External Attention}

As $\mathrm{H} 3$ mentioned above, the enterprise with stronger core competence can be motivated to fulfill more social responsibilities by greater external attention. Based on this, this paper uses the mediating effect model to test whether core competence can improve corporate social responsibility through increasing external attention. Referring to Du and Tan (2017), we use "analyst attention", that is, "the number of analysts (or teams) that have tracked and analyzed this company in that year" (ATT) to measure the external attention of the company(In order to ensure the robustness of the results, this paper also uses the "attention received by research reports" as the measurement of external attention, that is, the number of research reports analyzed on the company in that year, and tests the mediating effect, and the regression results are still robust.). Table 5 lists the test results. The first three columns list the mediating effect test results when CSR is taken to measure corporate social responsibility. The last three columns list the mediating effect test results when CSR_EXP is taken to measure corporate social responsibility. For the sake of being concise, taking the empirical results of CSR measurement of corporate social responsibility as an example to analyze (the mediating effect test results of CSR_EXP measurement of corporate social responsibility also support the conclusion). Firstly, Column 
1 shows the result of the first step of the mediating effect test. The core competence (CORE) coefficient is $0.880, t=5.68$, which is significantly positive at the $1 \%$ level. Secondly, Column 2 lists the result of the second step of the mediation effect test. The regression result shows that the coefficient of external attention (ATT) is $0.025, \mathrm{t}=2.11$, which indicates that the stronger the enterprises' core competence is, the higher the external attention it receives. Finally, Column 3 lists the result of the third step of mediating effect test. The regression result shows that after adding external attention (ATT) into the model, the ATT's coefficient is 0.967 ( $\mathrm{t}=9.30)$, which is significantly positive at the $1 \%$ level. The coefficient of core competence is $0.856, t=5.54$, which is significantly positive at the level of $1 \%$. In addition, the coefficient of core competence (CORE) in Column 3 decreases compared with that in Column 1. Besides, the regression results pass the Sobel Test of intermediary effect $(\mathrm{Z}=2.06 ; \mathrm{P}=0.04)$, indicating that the external attention (ATT) plays a partial intermediary role between core competence (CORE) and corporate social responsibility (CSR). In other words, enterprises with stronger core competence have a higher degree of market attention and can be promoted to fulfill more social responsibilities.

Tab. 5 - Mechanism Test: External Attention. Source: own research

\begin{tabular}{|c|c|c|c|c|c|c|}
\hline & CSR & ATT & CSR & CSR_EXP & ATT & CSR_EXP \\
\hline & (1) & (2) & (3) & (4) & (5) & (6) \\
\hline \multirow[t]{2}{*}{ CORE } & $0.880^{* * *}$ & $0.025^{* *}$ & $0.856^{* * *}$ & $0.581 * * *$ & $0.025^{* *}$ & $0.572^{* * *}$ \\
\hline & $(5.68)$ & $(2.11)$ & $(5.54)$ & $(4.18)$ & (2.11) & $(4.12)$ \\
\hline \multirow[t]{2}{*}{ AT'T } & & & $0.967 * * *$ & & & $0.355^{* * *}$ \\
\hline & & & $(9.30)$ & & & $(3.81)$ \\
\hline $\mathrm{CV}$ & YES & YES & YES & YES & YES & YES \\
\hline INDUSTRY & YES & YES & YES & YES & YES & YES \\
\hline YEAR & YES & YES & YES & YES & YES & YES \\
\hline $\mathrm{N}$ & 15585 & 15585 & 15585 & 15585 & 15585 & 15585 \\
\hline Adj-R ${ }^{2}$ & 0.35 & 0.64 & 0.35 & 0.20 & 0.64 & 0.20 \\
\hline
\end{tabular}

Note: $T$ values in brackets are obtained after heteroscedasticity (robust) correction; ***, ** indicate significance at $1 \%$ and $5 \%$ levels, respectively. "YES" or "NO" means if the result controls controlled variables (CV), industry effect (INDUSTRY), year effect (YEAR) or not.

\subsection{Further Research}

\subsubsection{Further Research: The Nature of Enterprise}

Theoretically, state-owned enterprises are a means for the state to participate in or intervene in the economy on behalf of the public interest. They shoulder a series of non-economic goals, such as helping the state to achieve economic development strategy, solving the imbalance of economic structure and calming down the economic cycle, and therefore often need to fulfill more social responsibilities (Zhang, 2013; Gu et al., 2020). Therefore, state-owned enterprises' social responsibility behaviors are more mandatory and less affected by their core competence. In contrast, non-state-owned enterprises' social responsibility is more affected by their own core competence. So, hypothesis $\mathrm{H} 4$ is proposed in this paper. 
H4: The impact of core competence on corporate social responsibility is expected to be more significant in non-state-owned enterprises.

To verify the above inference, this paper constructs the cross term (CORE $\times \mathrm{SOE}$ ) of core competence (CORE) and the nature of enterprise (SOE) and then puts it into the model (1) for regression. The regression results are shown in Table 6 . The results show that in the four regression results, the regression coefficients of the cross-term CORE $\times \mathrm{SOE}$ are significantly negative at the $1 \%$ or $5 \%$ level, indicating that for state-owned enterprises, the effect of core competence on corporate social responsibility is weaker. In contrast, the core competence of non-state-owned enterprises has a stronger impact on their social responsibility fulfillment, which is consistent with the theoretical analysis above.

Tab. 6 - Further Test: The Moderating Effect of Enterprise's Nature. Source: own research

\begin{tabular}{|l|l|l|l|l|}
\hline & CSR & CSR & CSR_EXP & CSR_EXP \\
\hline CORE & $2.276^{* * *}$ & $1.162^{* * *}$ & $1.148^{* * *}$ & $0.795^{* * *}$ \\
\hline & $(11.88)$ & $(7.21)$ & $(7.80)$ & $(5.52)$ \\
\hline CORE×SOE & $-1.557 * * *$ & $-0.927^{* * *}$ & $-1.024 * * *$ & $-0.706^{* *}$ \\
\hline & $(-3.88)$ & $(-2.64)$ & $(-3.18)$ & $(-2.24)$ \\
\hline SOE & $6.454^{* * *}$ & $4.013^{* * *}$ & $6.432^{* * *}$ & $3.874 * * *$ \\
\hline & $(5.91)$ & $(4.16)$ & $(7.35)$ & $(4.47)$ \\
\hline CV & NO & YES & NO & YES \\
\hline INDUSTRY & YES & YES & YES & YES \\
\hline YEAR & YES & YES & YES & YES \\
\hline N & 15585 & 15585 & 15585 & 15585 \\
\hline Adj-R ${ }^{2}$ & 0.12 & 0.35 & 0.15 & 0.20 \\
\hline
\end{tabular}

Note: $\mathrm{T}$ values in brackets are obtained after heteroscedasticity (robust) correction; ***, ** indicate significance at $1 \%$ and $5 \%$ levels, respectively. "YES" or "NO" means if the result controls controlled variables (CV), industry effect (INDUSTRY), year effect (YEAR) or not.

\subsubsection{Further Research: Industry Competition}

As an important achievement of competition-oriented strategic management theory, the value of core competence can be more fully reflected in the fierce market competition (Sun et al., 2021a; Sabah et al., 2012). For enterprises with poor core competence, their profit is greatly affected by market competition. When the market competition is fierce, the opportunity cost lost due to the fulfillment of social responsibility will rise sharply so that enterprises will reduce the investment in social responsibility (Sprinkle \& Maines, 2010; Zhou \& Tang, 2015). However, for enterprises with strong core competence, due to having competitive advantages which are difficult to be imitated by others, their competitive position in the industry is difficult to be surpassed by competitors in a short period of time, and their profit is less affected by the degree of industry competition. Therefore, even if the industry competition becomes more intense, enterprises with strong core competence can also provide sufficient financial support for social responsibility activities. In other words, core competence can guarantee that the enterprises still have the 
ability to fulfill social responsibility in the fierce market competition. In conclusion, in industries with more intense competition, the impact of core competence on corporate social responsibility is expected to be more significant. So, hypothesis H5 is proposed in this paper.

H5: The impact of core competence on corporate social responsibility is expected to be more significant in industries with more intense competition.

In order to verify the above inference, referring to Zhou \& Tang (2015) and Wang \& Shen (2018), this paper measures the degree of industry competition by using the Herfendahl index $(\mathrm{COMP})$ and constructs the cross term (CORE $\times \mathrm{COMP})$ of the core competence (CORE) and the Herfendahl index (COMP), and then puts it into the model (1) for regression. Since the Herfendahl index is a positive number greater than 0 , and the closer it approaches 0 , the higher the degree of market competition, it is expected that the regression coefficient (CORE $\times$ COMP) will be significantly negative. Table 7 lists the testing results of the moderating effect of industry competition. The results show that in the four regression results, the regression coefficients of the cross term $(\mathrm{CORE} \times \mathrm{COMP})$ are significantly negative, indicating that when the industry competition is higher, the impact of core competence on corporate social responsibility is more significant, which is consistent with the previous deduction results.

Tab. 7 - Further Test: The Moderating Effect of Industry Competition. Source: own research

\begin{tabular}{|l|l|l|l|l|}
\hline & CSR & CSR & CSR_EXP & CSR_EXP \\
\hline CORE & $2.209 * * *$ & $1.351^{* * *}$ & $0.800^{* * *}$ & $0.925^{* * *}$ \\
\hline & $(9.50)$ & $(6.70)$ & $(4.30)$ & $(5.07)$ \\
\hline CORE×COMP & $-11.434 * * *$ & $-8.147^{* * *}$ & $-6.232^{* * *}$ & $-5.967 * * *$ \\
\hline & $(-4.11)$ & $(-3.27)$ & $(-2.65)$ & $(-2.59)$ \\
\hline COMP & $25.843^{* * *}$ & $12.945^{* *}$ & 8.896 & 9.206 \\
\hline & $(3.68)$ & $(2.07)$ & $(1.50)$ & $(1.59)$ \\
\hline CV & NO & YES & NO & YES \\
\hline INDUSTRY & YES & YES & YES & YES \\
\hline YEAR & YES & YES & YES & YES \\
\hline N & 15585 & 15585 & 15585 & 15585 \\
\hline Adj-R ${ }^{2}$ & 0.11 & 0.35 & 0.13 & 0.20 \\
\hline
\end{tabular}

Note: $\mathrm{T}$ values in brackets are obtained after heteroscedasticity (robust) correction; ***, ** indicate significance at $1 \%$ and $5 \%$ levels, respectively. "YES" or "NO" means if the result controls controlled variables (CV), industry effect (INDUSTRY), year effect (YEAR) or not.

\section{DISCUSSION}

This study discusses the influence of core competence on corporate social responsibility, which complements the literature in the following ways.

Firstly, this paper finds a positive effect of core competence on fulfilling corporate social responsibility. The finding is similar to those reported in previous research, which generally 
found positive economic consequences of core competence (Ljungquist, 2013; Chen \& Chang, 2011; Sabah et al., 2012; Sun, 2014; Liang et al., 2013; Denicolai et al., 2010). The differences are as follows: Because of the difficulty in the measurement of core competence, previous researches were mainly based on theoretical analysis (Ljungquist, 2013; Chen \& Chang, 2011). There are several positive empirical pieces of evidence with small sample because they measured the level of core competence of enterprises using questionnaire survey (Sabah et al., 2012) or case study (Sun, 2014) or selected specific metrics to measure some particular kind of core competence of enterprises within a single industry (Liang et al., 2013; Denicolai et al., 2010). This paper is consistent with Sun et al. (2021a), which constructs the measurement index of enterprise core competence with the method of text analysis, which is large-sample evidence on the positive effect of core competence.

Secondly, this study shows that the impact of core competence on corporate social responsibility is realized through two ways, namely, enhancing financial strength and increasing external attention, clarifying the affecting mechanism of core competence on corporate social responsibility. The conclusion of this paper is consistent with previous researches (Liang et al., 2013; Denicolai et al., 2010; Sabah et al., 2012), which confirmed that core competence could improve the enterprises' financial performance. Besides, regarding the influencing factors of corporate social responsibility, scholars have studied the enterprise size (Ting, 2021), corporate governance (Arora \& Dharwadkar, 2011), financial performance (Zhang et al., 2013; Yin et al., 2014), corporate culture (Jin, 2017), external attention (Zyglidopoulos et al., 2012; Jia et al., 2016), the degree of market competition (Flammer, 2015; Zhou \& Tang, 2015) and so on. The conclusion of this paper is similar to previous researches, which confirmed that financial performance (Zhang et al., 2013; Yin et al., 2014) and external attention (Zyglidopoulos et al., 2012; Jia et al., 2016) were important to the implementation of social responsibility. The difference is that this study proves financial strength and external attention are the affecting mechanisms between core competence and corporate social responsibility.

\section{CONCLUSION}

Taking the non-financial companies listed in the A-share market in China from 2010 to 2019 as the research samples, this paper constructs the measurement index of corporate core competence through text analysis and empirically tests the impact of core competence on corporate social responsibility. We find that the stronger the core competence is, the higher the corporate social responsibility will be, which means core competence can significantly improve corporate social responsibility. This conclusion remains significant after a series of robustness tests. The mechanism test shows that the impact of core competence on corporate social responsibility is realized by enhancing financial strength and increasing external attention. Further research shows that the relationship between core competence and corporate social responsibility is affected by the nature of the enterprise and the degree of market competition. When the enterprise is a non-state-owned enterprise or the industry competition is more intense, the influence of core competence on corporate social responsibility is stronger. 
The research significance of this paper is embodied in two aspects: theoretical contribution and practical inspiration. In terms of theoretical contribution, based on the annual reports of Chinese A-share listed companies, this paper extracts the paragraphs in the annual reports of listed companies that refer to the core competence of enterprises by text analysis method, constructs the measurement index of the core competence of enterprises, and empirically tests the impact of core competence on corporate social responsibility. This not only enriches the literature on the economic consequences of core competence and the influencing factors of corporate social responsibility but also provides a useful reference for the subsequent empirical research on the topic of core competence. In terms of practical inspiration, in recent years, the Chinese government has begun to vigorously promote enterprises to fulfill their social responsibilities, and the corresponding rules and regulations, laws and regulations are also being constantly improved. The public's requirements for fulfilling corporate social responsibility are also increasing. This study shows that the enhancement of core competence is conducive to enhancing the degree of corporate social responsibility fulfillment, and this conclusion has certain guiding significance for the future strategic deployment of enterprises, the work direction of regulatory authorities and the decision-making of stakeholders.

The research in this paper also has certain limitations due to the fact that the core competence variable is constructed based on the core competence disclosed in the annual reports of listed companies in China. Some listed companies clearly state their company's core competence in their annual reports, while some companies do not make it clear enough. Therefore, there will inevitably be some noise in the process of text analysis of the annual report. If the China Securities Regulatory Commission requires all listed companies to disclose their core competence, the conclusions of this article will be more convincing.

Acknowledgment: This work was supported by the National Natural Science Foundation of China [grant number 72002006] and the Beijing Municipal Commission of Education [grant number SM202110011009].

\section{References}

1. Arora, P., \& Dharwadkar, R. (2011). Corporate Governance and Corporate Social Responsibility (CSR): The Moderating Roles of Attainment Discrepancy and Organization Slack. Corporate Governance: An International Review, 19 (2), 136-152. https://doi.org/10.1111/j.1467-8683.2010.00843.x

2. Chen, H., \& Chang, W. (2011). Core Competence: From A Strategic Human Resource Management Perspective. African Journal of Business Management, 5 (14), 5738-5745. https://doi.org/10.5897/AJBM11.045

3. Denicolai, S., Cioccarelli, G., \& Zucchella, A. (2010). Resource-based Local Development and Networked Core-competencies for Tourism Excellence. Tourism Management, 31 (2), 260-266. https://doi.org/10.1016/j.tourman.2009.03.002

4. Du, X., \& Tan, X. (2017). The Globalizing Board, Analyst Coverage, and Cash Dividend. Journal of Financial Research, 446 (8), 192-206. https://doi.org/10.12094/1002-7246 
5. Elliott, W. B., Jackson, K. E., Peecher, M. E., \& White, B. J. (2014). The Unintended Effect of Corporate Social Responsibility Performance on Investors' Estimates of Fundamental Value. Accounting Review, 89 (3), 275-302. http://dx.doi.org/10.2308/accr-50577

6. Flammer, C. (2015). Does Product Market Competition Foster Corporate Social Responsibility? Evidence from Trade Liberalization. Strategic Management Journal, 36 (10), 1469-1485. http://dx.doi.org/10.1002/smj.2307

7. Ghoul, S. E., Guedhami, O., Nash, R., \& Patel, A. (2019). New Evidence on the Role of the Media in Corporate Social Responsibility. Journal of Business Ethics, 154 (4), 1-29. http://dx.doi.org/10.1007/s10551-016-3354-9

8. Gu, L., Guo, J., \& Wang, H. (2020).Corporate Social Responsibility, Financing Constraints, and the Financialization of Enterprises. Journal of Financial Research, 2,109-127. https://doi.org/CNKI:SUN:JRYJ.0.2020-02-007

9. Jia, X., Liu, Y., \& Liao, Y. (2016). Stakeholders Pressure, Corporate Social Responsibility, and Firm Value. Chinese Journal of Management, 13 (2), 267-274. https://doi.org/10.3969/j.issn.1672884x.2016.02.013

10. Jin, X. (2017). Does Corporate Culture Effect Corporate Social Responsibility? Evidence from Listed Companies in Shanghai Stock Exchange. Accounting Research, 2, 56-62.

11. Kitzmueller, M., \& Shimshack, J. (2012). Economic Perspectives on Corporate Social Responsibility. Journal of Economic Literature, 50 (1), 51-84. http://dx.doi.org/10.1257/jel.50.1.51

12. Kong, D., Liu, S., \& Ying, Q. (2013). The Role of Media in Corporate Behavior: Igniting Turbulence or Promoting Clarity? Journal of Management World, 7, 145-162. https://doi.org/10.19744/j.cnki.11-1235/f.2013.07.013

13. Lazzarini, S. G. (2015). Strategizing by the Government: Can Industrial Policy Create Firmlevel Competitive Advantage? Strategic Management Journal, 36 (1), 97-112. https://doi.org/10.1002/smj.2204

14. Li, B., Wang, B. \& Qing, X. (2018). Corporate Social Responsibility, Media Supervision, and Financial Performance - Empirical Data Based on A Share Heavy Pollution Industry. Accounting Research, 7, 64-71.

15. Li, Z., Ruan, D., \& Zhang, T. (2020).Value Creation Mechanism of Corporate Social Responsibility: A Study Based on Internal Control. Accounting Research, 11, 112-124.

16. Liang, C. , Lin, Y., \& Huang, H. (2013). Effect of Core Competence on Organizational Performance in an Airport Shopping Center. Journal of Air Transport Management, 31 (8), 23-26. https://doi.org/10.1016/j.jairtraman.2012.11.005

17. Lins, K. V., Servaes, H., \& Tamayo, A. (2017). Social Capital, Trust, and Firm Performance: The Value of Corporate Social Responsibility During the Financial Crisis. The Journal of Finance, 72 (4). http://dx.doi.org/10.1111/jofi.12505

18. Ljungquist, U. (2013). Specification of Core Competence and Associated Components. European Business Review, 20 (1), 73-90. https://doi.org/10.1108/09555340810843708

19. Lu Y., \& Sun, J. (2013). A New Perspective on the Growth Strategy of Chinese Enterprises: The Concept, Connotation and Method of Compound-based View. Journal of Management World, 10, 106-188. 
20. Lys, T., Naughton, J. P., \& Wang, C. (2015). Signaling Through Corporate Accountability Reporting. Journal of Accounting and Economics, 60 (1), 56-72.

https://doi.org/10.1016/j.jacceco.2015.03.001

21. Madsen, T. L. , \& Leiblein, M. J. (2015). What Factors Affect the Persistence of an Innovation Advantage? Journal of Management Studies, 52 (8), 1097-1127.

http://dx.doi.org/10.1111/joms.12154

22. Porter M. E., \& Kramer, M. R. (2011). The Big Idea: Creating Shared Value. How to Reinvent Capitalism and Unleash a Wave of Innovation and Growth. Harvard Business Review, 89 (1), 62-77.

23. Sabah, A., Laith, A., \& Manar, J. (2012). Effect of Core Competence on Competitive Advantage and Organizational Performance. International Journal of Business and Management, 7 (1), 192-204. http://dx.doi.org/10.5539/ijbm.v7n1p192

24. Servaes, H., \& Tamayo, A. (2013). The Impact of Corporate Social Responsibility on Firm Value: The Role of Customer Awareness. Management Science, 59 (5), 1045-1061. http://dx.doi.org/10.1287/mnsc.1120.1630

25. Sprinkle G. B., \& Maines, L. A. (2010). The Benefits and Costs of Corporate Social Responsibility. Business Horizons, 53 (5), 445-453. https://doi.org/ 10.1016/j.bushor.2010.05.006

26. Sun, C. (2014). An Exploration of Core Competences of Newly Qualified Nurses: A Case Study. Quality \& Quantity, 48 (2), 767-780. https://doi.org/10.1007/s11135-012-9801-5

27. Sun, C., Wang, H., Qi, Y., \& Sun, Y. (2021a). Can Core Competence Help Enterprises to Deleverage? - Empirical Evidence Based on Text Analysis. Personal and Ubiquitous Computing. https://doi.org/10.1007/s00779-020-01491-3

28. Sun, C., Wang, H., \& Wang, P. (2021b). Influence of Corporate Core Competence on Supply Chain Finance: Financial Support or Occupation? China Soft Science, 6, 120-134.

29. Tao, W., \& Jin, Z. (2012). The Relationship among Corporate Social Responsibility Disclosure, Media Exposure and Corporate Financial Performance. Chinese Journal of Management, 8, 1225-1232. https://doi.org/10.3969/j.issn.1672-884X.2012.08.017

30. Ting, P. H. (2021). Do large firms just talk corporate social responsibility? - the evidence from CSR report disclosure. Finance Research Letters, 38, 101476. https://doi.org/10.1016/j.frl.2020.101476

31. Wang, B., Yang, Y., \& Sun, C. (2021a). Does Core Competence Make a Significant Impact on Audit Decisions? An Empirical Study Based on A-share Listed Companies. Auditing Research, (02), 68-79.

32. Wang, C., Brabenec, T., Gao, P., \& Tang, Z. (2021b). The Business Strategy, Competitive Advantage and Financial Strategy: A Perspective from Corporate Maturity Mismatched Investment. Journal of Competitiveness, 13 (1), 164-181. https://doi.org/10.7441/joc.2021.01.10

33. Wang, F., \& Shen, L. (2018). The Impact of Product Market Competition on Auditor's Risk Response. Auditing Research, 6, 81-89. https://doi.org/10.3969/j.issn.1002-4239.2018.06.012 
34. Wang, J., Li, Y., \& Wu, X. (2018). Corporate Social Responsibility as the Signal of Firm Future Performance: Evidence from Chinese Market. Chinese Journal of Management Science, 26 (8), 31-41. https://doi.org/10.16381/j.cnki.issn1003-207x.2018.08.004

35. Wang, Q., \& Xu, X. (2016). Research on the Value-Creation Mechanism of Corporate Social Responsibility and Its Empirical Test Based on the Stakeholder Theory and Life Cycle Stage Theory. China Soft Science, 2, 179-192.

36. Wang, S., Gao, Y., Hodgkinson, G. P., Rousseau, D. M., \& Flood, P. C. (2015). Opening the Black Box of CSR Decision Making: A Policy-capturing Study of Charitable Donation Decisions in China. Journal of Business Ethics, 128, 665-683. http://dx.doi.org/10.1007/s10551-014-2123-x

37. Wu, L. Z., Kwan, H. K., Yim, H. K., Chiu, R. K., \& He, X. (2015). CEO Ethical Leadership and Corporate Social Responsibility: A Moderated Mediation Model. Journal of Business Ethics, 130 (4), 819-831. https://doi.org/10.1007/s10551-014-2108-9

38. Wu, N. (2013). Dynamic and Synergic Selection between Economic Cycles, Financing Constraints and Working Capital. Accounting Research, (8), 54-61.

39. Yin, K., Liu, X., \& Chen, H. (2014). Study on the Relationship between Corporate Social Responsibility and Financial Performance from the Endogenous Perspective-Evidence from Chinese Listed Companies. China Soft Science, (6), 98-108.

40. Zhang, J. (2013). Competition-Commitment-Compliance: The Motivation of Corporate Philanthropic Donation in China. Journal of Management World, (9), 118-129.

41. Zhang, K., \& Gao, Q. (2013). Research on the Construction of Enterprise's Core Competence Based on Breakthrough Technological Innovation. Journal of Management World, 6, 180-181.

42. Zhang, Z., Jin, X., \& Li, G. (2013). An Empirical Study on the Interactive and Intertemporal Influence between Corporate Social Responsibility and Corporate Financial Performance. Accounting Research, 08, 32-39.

43. Zhou, H., \& Tang, L. (2015). Can Market Competition Force Companies to Treat Employees Well? Micro-evidence from manufacturing companies. Journal of Management World, 11, 135-144. https://doi.org/10.19744/j.cnki.11-1235/f.2015.11.015

44. Zhou, Z., He, D., \& Li, Z. (2012). Institutional Environment and Corporate Social Responsibility: Evidence from Listed Companies in China. China Soft Science, (10), 59-68.

45. Zhu, S. (2011). Corporate Social Responsibility, Market Evaluation and Informativeness of Accounting Earnings. Accounting Research, (11), 27-34.

46. Zyglidopoulos, S. C., Georgiadis, A. P., Carroll, C. E., \& Siegel, D. S. (2012). Does Media Attention Drive Corporate Social Responsibility? Journal of Business Research, 65 (11), 1622-1627. http://dx.doi.org/10.1016/j.jbusres.2011.10.021 
Contact information

Postdoctor. Changling Sun, Ph.D.

Beijing Normal University

Business School

Department of Business Management

China

E-mail: sunchangling@bnu.edu.cn

ORCID: 0000-0003-1597-3924

Prof. Ing. et Ing. Stanislav Škapa, Ph.D.

Institute of Economics

Faculty of Business and Management,

Brno University of Technology

Crech Republic

E-mail:skapa@fbm.vutbr.cz.

ORCID: 0000-0002-9681-0061

Assoc. Prof. Jinzhao Liu, Ph.D. (Corresponding author)

Beijing Technology and Business University

Business School

Department of Finance

China

E-mail:liujz@btbu.edu.cn

ORCID: 0000-0002-3453-7338

Ing. Jakub Horak

School of Valuation and Expertness

Institute of Technology and Business

Ceské Budéjovice

Crech Republic

E-mail: horak@mail.vstecb.cr.

ORCID: 0000-0001-6364-9745

Yaning Yang, Postgraduate. Student

Renmin University of China

Business School

Department of Finance

China

E-mail:yyn06170@qq.com

ORCID: 0000-0002-4188-037X 